[RAdiocarbon, Vol 22, No. 2, 1980, P 349-362]

\title{
MINI-RADIOCARBON MEASUREMENTS, CHEMICAL SELECTIVITY, AND THE IMPACT OF MAN ON ENVIRONMENTAL POLLUTION AND CLIMATE*
}

\author{
LLOYD A CURRIE, GEORGE A KLOUDA, \\ National Bureau of Standards, Washington, DC 20234 \\ and \\ JOHN A COOPER \\ Oregon Graduate Center, Beaverton, Oregon 97005
}

\begin{abstract}
Underlying principles and results are presented for our program to use isotopic and chemical methods to quantify anthropogenic and natural sources of carbonaceous pollutants. Radiocarbon data have been obtained with a speciallydeveloped miniature low-level gas counting system which has permitted us to assay samples containing as little as $5 \mathrm{mg}$ carbon. Measurements of carbonaceous particles, using chemical selectivity and size fractionation to supplement the radiocarbon data, have revealed major impact from both fossil fuel and vegetative (contemporary) sources on urban aerosols. Residential wood-burning has been specifically identified as an important source of respirable particles. Current investigations are directed toward the carbonaceous gases and the application of the accelerator technique for the assay of radiocarbon in individual chemical fractions containing microgram quantities of carbon.
\end{abstract}

\section{Atmospheric contaminants: source characterization and effects}

Statement of the problem

At the previous (1976) International Radiocarbon Conference we outlined a program to apply radiocarbon measurements of selected atmospheric species (carbonaceous gases, particles) to derive relatively unambiguous information on the anthropogenic component (Currie, Noakes, and Breiter, 1979). Such measurements are important because many of the carbonaceous species have deleterious environmental effects, yet there is considerable uncertainty concerning the impact of man's activities as compared to that of natural sources (Rasmussen, 1972; Bolin, 1977). Biogenic (forest) emissions, for example, have been cited in cases of urban pollution episodes, and transport of fossil (industrial) hydrocarbons, in rural (photochemical oxidant) pollution episodes (Rasmussen, 1972; Coffey and Stasink, 1975; Novakov, 1978).

Carbonaceous species of primary concern in our overall program are those that may influence health, climate, or stratospheric ozone. The first category includes both the non-methane hydrocarbons and respirable particles. Such particles present a special hazard because they can be transported relatively great distances, and they generally contain Polycyclic Aromatic Hydrocarbons (PAH), a product of incomplete combustion that includes both mutagens and carcinogens (Novakov, 1978; Hall and others, 1978). The earth's radiation balance may be influenced by aerosols also, through radiation absorption, albedo effects, and cloud nucleation; and persistent gaseous species may lead to an enhanced "greenhouse" effect $\left(\mathrm{CO}_{2}, \mathrm{CH}_{4}, \ldots\right)$ or to destruction of stratospheric ozone (halocarbons-eg, $\mathrm{CCl}_{2} \mathrm{~F}_{2}$ ) (Geophysics Study Committee, 1977;

* Contribution of the National Bureau of Standards; not subject to copyright. 
Rowland and Molina, 1975). Also important are indirect (greenhouse, ozone) effects connected with increases in tropospheric lifetimes and mixing ratios $\left(\mathrm{CH}_{4}, \mathrm{CH}_{3} \mathrm{CCl}_{3}\right)$ due to consumption of $\mathrm{OH}$ radicals; such effects could follow, for example, from increased $\mathrm{CO}$ emissions (Logan and others, 1978; Altshuler, 1978).

\section{Source assessment methods; the role of radiocarbon}

Our objective, the assessment of man's contributions to the above species, may be approached through: 1) dispersion modeling (based on knowledge of emissions inventories, atmospheric transport and reactions, and bio- and geochemical sinks), 2) chemical characterization (compositional data) of the ambient species together with that of sources, and 3) isotopic measurements. Important inferences follow from the first two approaches, but they are sometimes ambiguous because of system complexity or measurement limitations. The isotopic approach, however, when the underlying two-source assumption is satisfied, is capable of yielding definitive information. That is, if the anthropogenic and natural sources of a given carbonaceous contaminant $\left(\mathrm{eg}, \mathrm{CH}_{4}\right.$ ) have distinctive and known isotopic compositions, one may deduce the relative contribution of each by measurement of the isotopic composition of the ambient sample of interest.

Attempts to employ ${ }^{13} \mathrm{C}$ for this purpose have met with partial success, but its use has been limited due to isotopic variations within source categories. For example, although it is possible to distinguish between carbon arising wholly from marine plants $\left(\delta^{13} \mathrm{C}_{\mathrm{PDB}} \approx-20 \%\right.$ ) and that wholly from land plants $\left(\delta^{13} \mathrm{C}_{\mathrm{PDB}} \approx-27 \%\right.$ ), the range of values within these two classes $(Z \pm 3 \%$ ) make the assignment of relative contributions, when both sources are operating, rather imprecise. The situation is worse if the distinction is made between carbon from terrestrial vegetation and that from petroleum: in this case, there is a broad overlap of the $\delta^{13} \mathrm{C}$ values (Troughton, 1972; Calder and Parker, 1968; Schutz and Renwick, 1977).

Radiocarbon, on the other hand, can serve as a unique discriminator when the two sources in question represent biogenic ("living") and fossil ("dead") carbon. Observation of the ${ }^{14} \mathrm{C} /{ }^{12} \mathrm{C}$ ratio in an ambient sample, relative to the same ratio in the living biosphere, gives a direct measure of the biospheric contribution to carbonaceous material sampled. Provided that the effects of recent atmospheric ${ }^{14} \mathrm{C}$ contamination (nuclear testing) are properly taken into account, the uncertainty of the result is limited by measurement error rather than source variations. When an ambient sample does not represent a pure chemical substance however, as in the case of carbonaceous particles or mixed hydrocarbon gases, we have found that more definitive conclusions may be obtained through chemical/physical selectivity, $i e$, the combination of methods 2), compositional characterization, and 3), isotopic measurements, above. This is illustrated in the discussion below of carbonaceous particles, where we combined radiocarbon measurements with "parallel" (elementary composition) and "serial" (size-fractionated particles) selectivity to 
generate more reliable results than would have been possible using either method alone (Cooper, Currie, and Klouda, in press). In effect, radiocarbon, acting as a unique biogenic tracer, served to validate the inferences resulting from the chemical measurements.

Environmental radiocarbon measurement requirements are stringent, especially when individual chemical or size fractions must be assayed. The current ${ }^{14} \mathrm{C}$ activity level of biospheric carbon is approximately $8 \mathrm{fCi} / \mathrm{mg}-\mathrm{C}$, and tropospheric concentrations of most of the species of interest range from about $10^{-5}$ to $1 \mathrm{mg}$-carbon/ $/ \mathrm{m}^{3}$-air (Currie, Noakes, and Breiter, 1979). Sampling limitations, thus, dictate that radiocarbon be determined in samples having, at best, tens of milligrams of carbon; for the rarer species, samples will be nanogram- to microgramsize domain. As a result, our program to date has been directed toward the more abundant trace gases and atmospheric particles; measurements have been made practicable for samples containing as little as $5 \mathrm{mg}$ carbon through the development of a specially-designed mini-radiocarbon counting system (Currie and others, 1978). Most recently, as noted in the final section of this paper, the development of the direct atom-counting method of Accelerator Mass Spectrometry (Muller, 1977; Gove, 1978) has enormously enhanced our potential to derive environmental information from radiocarbon measurements, as samples containing only a few tens of micrograms of carbon may now be analyzed (Currie and others, ms in preparation).

\section{Application of isotopic and chemical methods to carbonaceous pollutants}

\section{Survey of some recent studies}

Three of the studies that have been made since the last International Radiocarbon Conference are highlighted in figure 1. In all cases, radiocarbon measurements were supplemented by serial or parallel chemical selectivity ("supporting data" - last column), and sample sizes (with one exception) consisted of about $10 \mathrm{mg}$ carbon. As noted in Currie, Noakes, and Breiter (1979), the first ${ }^{14} \mathrm{C}$ measurements to determine the anthropogenic contribution to atmospheric particles were made by Clayton, Arnold, and Patty (1955) and Lodge, Bien, and Suess (1960). Both groups of workers used conventional radiocarbon counting techniques, requiring grams of carbon; and their samples represented ambient particles from very large volumes of urban air. In the second (1960) experiment, some chemical steps were taken (solvent extraction) to limit erratic results from non-representative organic debris. Results of these early experiments indicated a major fossil carbon contribution ( 60 to 90 percent) to the urban aerosol.

The first measurements on small samples of carbonaceous aerosols were completed early in 1978, using miniature low-level gas proportional counters with samples containing as little as 5 to $10 \mathrm{mg}$ of carbon. These studies (top portion of figure 1) were also directed toward ambient aerosols (Currie and others, 1978). Unlike the prior investigations, how- 
ever, sampling sites included both urban and rural locales, and considerable organic chemical characterization was included in the study. As anticipated, the urban sites showed largely fossil carbon ( 75 percent), and the rural site, little ( $\sim 10$ percent), if any. The organic characterization, which was aimed at defining the composition of the primary (source) carbonaceous material in one of the urban samples, was accomplished via solvent extraction, thermogravimetry and pyrolysisgas chromatography-mass spectrometry. Results were consistent with the radiocarbon observations, in that a major fraction of the primary material was graphitic with large amounts of alkanes, alkenes, and cyclic and aromatic hydrocarbons, normally associated with fossil fuel and combustion processes. Figure 2 shows the thermogram for the insoluble carbonaceous material of one of the urban samples (Los Angeles), indicating that about one-third of the carbon was "elemental" (nonvolatile). Information on this component of atmospheric particulate matter is of special interest because of its effect on radiation absorption, its catalytic activity, and because it is believed to be relatively stable during atmospheric transport, thus reflecting primary source carbon (Novakov, 197). A pyrogram of the non-elemental (polymeric) component for the urban sample (Salt Lake City) is shown in figure 3; most of the carbon compounds seen here are characteristic of fossil fuels.

The second study in figure 1 (impact particles) again dealt with anthropogenic particulate pollution, but, in this case, in relation to the

\section{RADIOCARBON IN AEROSOLS AND SEDIMENT}

\begin{tabular}{|c|c|c|c|}
\hline & Mass-Carbon (mg) & $\begin{array}{l}\% \text { Contemporary }\left[14 \mathrm{C} /{ }^{12} \mathrm{C}\right] \\
( \pm \text { one standard deviation) }\end{array}$ & Supporting Data \\
\hline \multicolumn{4}{|l|}{ Ambient Particles } \\
\hline Los Angeles & 7.8 & $23 \pm 15$ & Organic (insoluble) \\
\hline Salt Lake City & 5.3 & $28 \pm 13$ & Composition \\
\hline Utah Desert & 10.2 & $88 \pm 16$ & \\
\hline \multicolumn{4}{|l|}{ Impact Particles $(<3 \mu \mathrm{m})$} \\
\hline Portland, OR. & $5.1-10.7$ & 62. -107. & Inorganic Composition \\
\hline \multicolumn{4}{|l|}{ Sediment } \\
\hline \multirow[t]{2}{*}{ Puget Sound, WA.fFA } & 60. & $86 \pm 21$ & Isotopic $\left({ }^{13} \mathrm{C} /{ }^{12} \mathrm{C}\right)$ \\
\hline & 14. & $19 \pm 21$ & Composition \\
\hline $\begin{array}{l}\text { Fig 1. Percent } \\
\text { measurements on sma } \\
\text { and isotopic }\left({ }^{13} \mathrm{C}\right) \text { da } \\
\text { others }(1978) \text {; Cooper } \\
\text { (ms in preparation). }\end{array}$ & $\begin{array}{l}\text { contemporary } \\
(-10 \mathrm{mg}) \text { enviro } \\
\text { aided in sou } \\
\text { Currie, and Klo }\end{array}$ & $\begin{array}{l}\text { tenic) carbon deduced } \\
\text { ital samples. Supportin } \\
\text { esolution/confirmation } \\
\text { (in press); Swanson, }\end{array}$ & $\begin{array}{l}\text { from radiocarbon } \\
\text { inorganic, organic, } \\
\text { Refs: Currie and } \\
\text { irhall, and Currie }\end{array}$ \\
\hline
\end{tabular}


urban impact of vegetative burning, hence, the large percentage of contemporary (biogenic) carbon in the samples. Because of the rather extensive nature of this investigation, which included particle size fractionation and parallel supporting inorganic chemical data, it has been selected for a fuller treatment in the following section. The study was motivated by the desire to develop a unique set of isotopic and chemical tracers for the resolution of the multiplicity of aerosol pollution sources in the Portland and Eugene, Oregon airsheds (Cooper, Currie, and Klouda, in press).

The lower portion of figure 1 includes some results of a cooperative study with scientists at the University of Washington, related to the organic fraction of sediment in Puget Sound (Swanson, Fairhall, and Currie, $m s$ in preparation). Objectives of the research were to trace the chemical consequences in the marine environment of fossil fuel use and biospheric carbon sources as a function of time (depth) and location, and more specifically, to investigate the question as to the existence of a natural marine source for polycyclic aromatic hydrocarbons (PAH). Contradictory hypotheses regarding the origin of $\mathrm{PAH}$ in sediment, one suggesting forest fires (Blumer and Youngblood, 1975) and the other, fossil fuel combustion (Hites, LaFlamme, and Farrington, 1977), are both based on chemical inference (molecular weight distributions of selected organic species). The amounts of contemporary carbon found in our measurements, which relate to sediment deposited during the last two decades, demonstrate that a fossil source was responsible for the PAH, but a biogenic source, for the metabolized fatty acids (FA). The extremely small abundance of the PAH in this case dictated the use of the miniradiocarbon technique, because the extraction of a metric ton of sediment would have been required had conventional radiocarbon counting been employed. The widely different ${ }^{14} \mathrm{C}$ concentrations in the various organic fractions would make ${ }^{14} \mathrm{C}$ results on non-separated material misleading. (This is exactly analogous to the distortion of radiocarbon dates that results from archaeologic or geologic samples containing

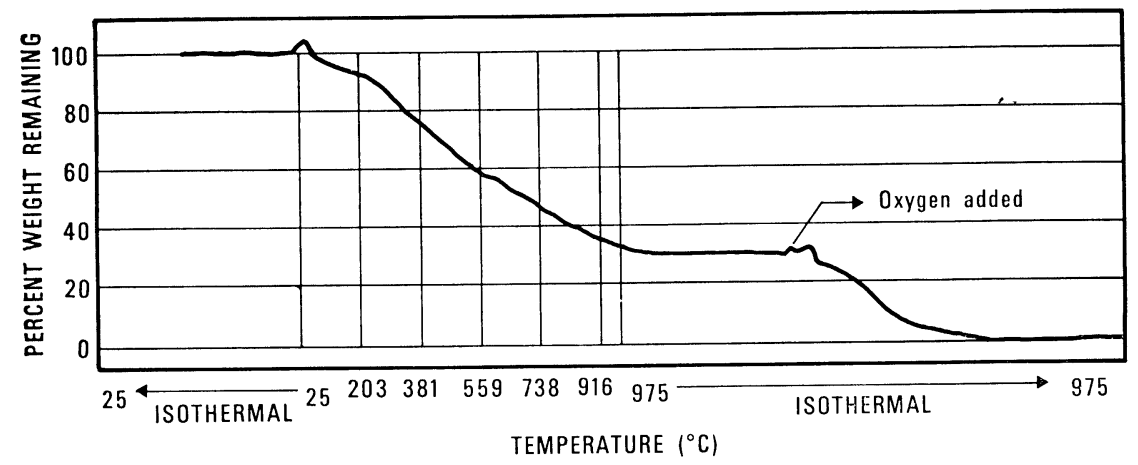

Fig 2. Thermogravimetric analysis of urban (Los Angeles) atmospheric particulate sample. Two-thirds of the insoluble carbonaceous material was volatile as shown by the weight loss prior to the admission of oxygen (Currie and others, 1978). 


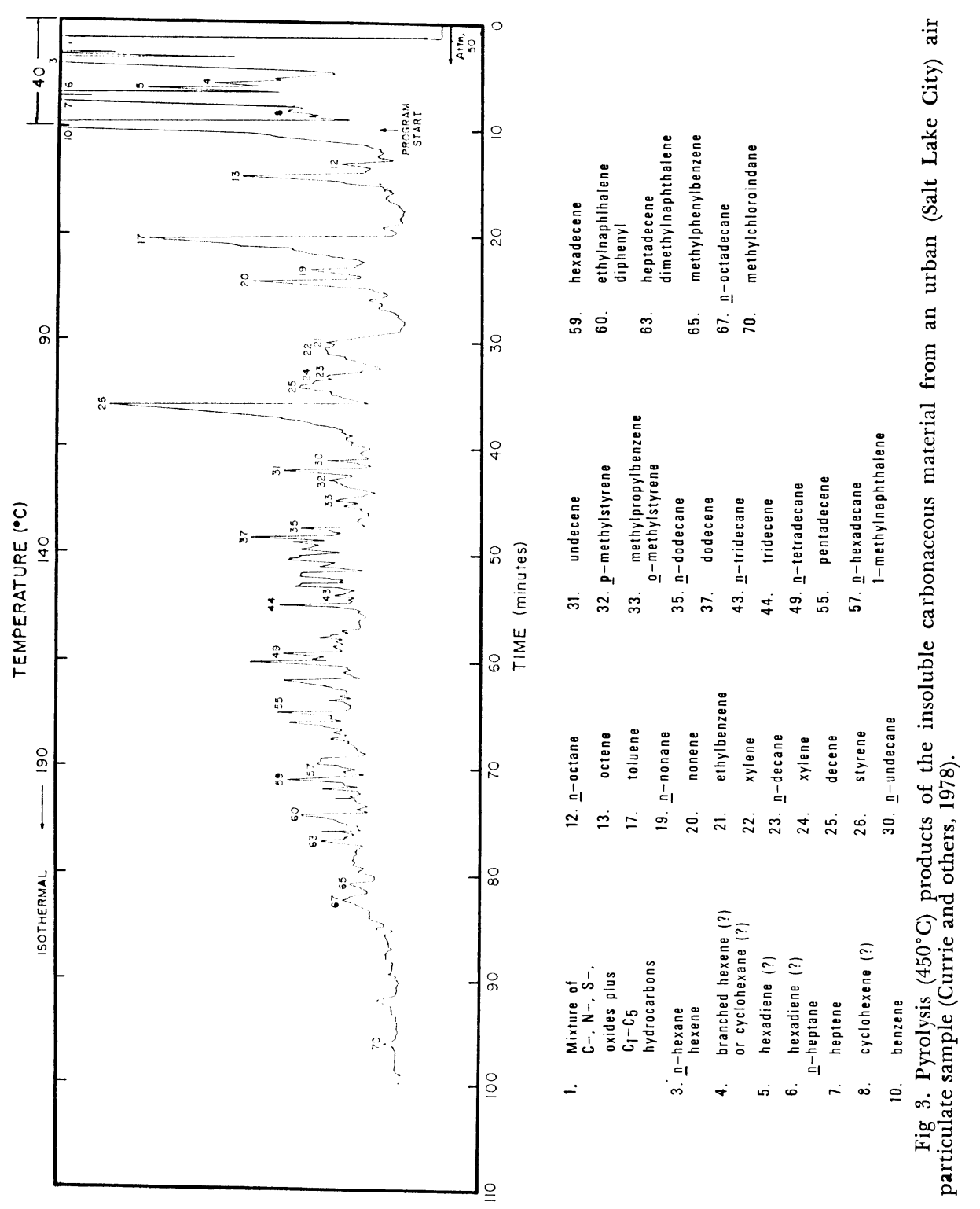


non-contemporaneous material.) Parallel measurement of ${ }^{13} \mathrm{C}$ (not shown in the figure) provided complementary information in this case. Based on the ${ }^{13} \mathrm{C}$ concentrations in marine and terrestrial organic matter, it was estimated that about two-thirds of the carbon in the fatty acid fraction were terrestrial in origin.

\section{Characterization of urban particulate material via chemical} mass balance (CMB) and radiocarbon measurements

\section{1) Background information}

The "impact particle" study (fig l) is being given special emphasis because it demonstrates both the practical value of radiocarbon as a biogenic tracer and the considerable power of the method when combined with ancillary physical, chemical, and meteorologic data. The investigation focused specifically on the problem of identifying sources of particulate pollution in the Portland and Eugene, Oregon airsheds, a matter of some urgency because these regions have been designated as "nonattainment areas" (frequently unable to meet the air quality standards for particulates). Initially, the problem was attacked by the application of Chemical Mass Balance (CMB), wherein elemental compositional patterns of ambient particles are matched with those of potential sources. This approach has been successful for identifying many sources of atmospheric particles (Friedlander, 1973; Cooper, Watson, and Huntzicker, 1979), but its utility is somewhat limited in discriminating sources of carbonaceous particles (uncertainties typically range from 20 to 40 percent for vegetative sources). The reasons for this limitation are twofold: the inorganic component of the carbonaceous particles is quite small, and the inorganic composition is variable, depending upon the exact nature of the material burned, combustion conditions, etc. On the other hand, carbon accounts for up to 40 to 50 percent of the urban particulate mass during air pollution episodes, and it is largely associated with the respirable (fine particle) fraction that carries chemical carcinogens and is largely responsible for radiation absorption and visibility degradation (Cooper, Currie, and Klouda, 1979; Novakov, 1978).

Because of the grass seed and lumber industries in the Northwest, vegetative burning ("field" burning of grass stubble, and "slash" burning of lumbering remains) constitutes a major source of carbonaceous particles. As with most automotive and industrial emissions, such carbon is primarily associated with the fine particle fraction $(<3 \mu \mathrm{m}$, equivalent aerodynamic diameter), and the characteristic diffusive flame during such burning favors incomplete combustion. The resulting particles contain some elemental (graphitic) carbon and large amounts of volatilizable (polymeric) carbon. By combining radiocarbon measurements with particle size fractionation and CMB, as shown below, we not only confirmed the suspected impact of the field and slash burning, but we also obtained direct evidence of significant carbonaceous particulate pollution from natural emissions and from residential wood combustion. 
2) Approach and results

The task of estimating individual source strengths would be ideally attacked through the use of natural tracers which are unique to each contributing source. This may be approached, for example, by employing ${ }^{14} \mathrm{C}$ as a tracer for vegetative carbon and $\mathrm{Pb}$ as a tracer for automobile emissions. Because of particle transformations and because a given element (isotope) occurs in various sources, however, complete and reliable resolution can seldom be achieved through this means. As a result, we have adopted a composite approach that incorporates both elemental $(\mathrm{CMB})$ and isotopic $\left({ }^{14} \mathrm{C}\right)$ analyses. The $\mathrm{CMB}$ method is based on the assumption that the particulate mass collected at a receptor site is a superposition of the amounts contributed from each of the sources, and that mass and chemical speciation are conserved. If this is the case,

where

$$
\mathrm{C}_{\mathrm{i}}=\sum_{\mathrm{j}} \mathrm{F}_{\mathrm{ij}} S_{\mathrm{j}}
$$

$\mathrm{C}_{\mathrm{i}}=$ concentration of the ith chemical species measured at a receptor site;

$\mathbf{F}_{\mathrm{ij}}=$ fraction of the ith chemical species in the aerosol emitted by the jth source;

$S_{j}=$ fraction of the mass collected at a receptor site contributed by the jth source.

The concentration and source profiles $\left(\mathrm{C}_{\mathrm{i}}\right.$ and $\left.\mathrm{F}_{\mathrm{ij}}\right)$ are determined empirically by chemical analysis of ambient and source material on air filters, respectively, and the source strengths $\left(S_{j}\right)$ are computed from Eq (1) using an effective variance method of least squares (Watson, 1979). The complete investigation of Portland aerosol sources, as reported by Cooper, Watson, and Huntzicker (1979) involved the characterization of 37 sources (representing 95 percent of the emission inventory) for each of 27 chemical species. Their analyses of ambient urban particles, which took into account two size fractions and a number of meteorologic regimes, indicated that the primary aerosol could be attributed to the following sources: geologic (39 percent of the mass), vegetative burning (15 percent), automotive exhaust (10 percent), and nine classes of industrial sources ( 5 percent). Unidentified sources ( 8 percent) and secondary aerosol accounted for the remainder of the mass.

In order to obtain optimal source resolution and reliability, the above parallel (chemical, isotopic) approach has been carried out with samples that were preselected according to particle size, sampling time, and collection site (for maximum impact). Fine particles are of special interest, because they may be formed directly during the combustion of vegetation or fossil fuel, or as secondary products of botanical emissions, such as terpenes and isoprene. Selection of such particles, thus, yields the most reliable, and most important, information of both fossil fuel and vegetative carbon sources. This is evident from table 1 , which comprises a brief catalogue of carbonaceous sources as a function of particle size and 
“age”. The importance of size segregation became even more evident in subsequent analyses of radiocarbon in both fine and total suspended particulate fractions.

Results of radiocarbon measurements on particles selected to maximize three different vegetative burning impact categories are presented in table 2. The final column in the table refers to the percent of 1978 carbon that would be expected if all of the carbon present were due to the vegetative source in question. With the exception of the "no vegetative) burning" day, the model values all lie close to 100 percent, differing only because of the age of the typical residential wood (40 years) or slash burn wood ( 75 years). The model values were derived by integrating over the bomb carbon input function (Lopes and others, 1975) and correcting for radioactive decay. Taken as a whole, these data support the conclusion that on those days of maximum field and slash burning, the fossil carbon content of the respirable urban particles was quite small. It is noteworthy that, with one exception, the only significant discrepancies with the model values were seen for non-size segregated (total) samples; but these are the very samples for which local, large particle contaminants (table 1) are likely to produce misleading results. Sample number 6 , which shows the greatest model discrepancy, indicates a large biogenic component even though there was no vegetative burning during sampling. This sample was collected at the end of a two-week period of hot stagnant weather, however, and we can infer from the CMB analysis that up to half of the carbon content may be due to secondary particles formed from gaseous vegetative emissions (Cooper, Currie, and Klouda, 1979).

Table 3 gives a comparison of the radiocarbon data, here normalized for the model values, with other qualitative and semiquantitative vegetative burning indicators. The severity of these episodes is given by the last column, which lists the concentration of respirable carbonaceous particles in the urban atmosphere. Although the three types of support-

TABLE 1

Carbonaceous aerosols

Contemporary carbon sources

- Large particle sources

- Spores, pollen,...

- Vegetative fragments (leaves, grass, ... .

- Anthropogenic sources (paper, sawdust, . . .)

- Secondary particulates (gaseous emissions from foliage, vegetative burning, biogenic vapors)

- Primary particulates (from forest fires; slash, field and refuse burning; home heating with wood; hog fuel boilers)

Fossil carbon sources

- Large particle sources

- Tire rubber

- Carbonate minerals

- Fossil fuels (coal, oil, gas) and their utilization products 
ing data (columns 4-6) are all generally consistent with the radiocarbon observations, only the isotopic measurements can provide a direct measure of the biogenic component. The "budget estimate," which is more reliable for fine than for coarse particles, was computed from the CMB data for $\mathrm{Si}, \mathrm{Ni}$, and $\mathrm{Pb}$; these elements served as tracers for fossil carbon associated with road dust and soil, residual oil, and auto exhaust, respectively. These resulting fossil carbon contributions were then combined (together with a contribution for distillate oil deduced from the emission inventory ratio) and subtracted from the observed total carbon.

The ratios $\mathrm{K} / \mathrm{Fe}$ and Fine/Total are both qualitative indicators for vegetative burn particles as shown by Core and Terraglio (1978). Considering just the principal sources for aerosol $\mathrm{K}$ and $\mathrm{Fe}$, vegetation and soil, respectively, these authors have concluded that vegetative burn particles should be characterized by a ratio $(\mathrm{K} / \mathrm{Fe})$ significantly greater than unity. The large fraction of fine particles also is consistent evidence for a biogenic source (vegetative burning or secondary aerosol), but it is not by itself conclusive, because a similar result could arise from fossil fuel combustion.

One of the most significant conclusions from our investigation, as given in the bottom line of table 3 , is the important contribution of residential wood burning. Further perspective to this problem is given in figure 4 . The basic issues here are that economic pressures are making wood increasingly attractive as a fuel, and that its widespread use in uncontrolled residential wood-burning stoves has already been demonstrated by our radiocarbon measurements and Butcher's (1978) emission

TABLE 2

Contemporary (1978) carbon in Oregon aerosols*

\begin{tabular}{|c|c|c|c|c|c|c|c|}
\hline Sample & Date & $\begin{array}{c}\text { Sitef } \\
\text { ID }\end{array}$ & $\begin{array}{c}\text { Impact } * * \\
\text { class }\end{array}$ & $\begin{array}{c}\text { Concen- } \\
\text { tration } \\
\left(\mu \mathrm{g} / \mathrm{m}^{3}\right)\end{array}$ & $\begin{array}{c}\text { Size } \\
\text { fraction }\end{array}$ & $\begin{array}{c}\text { Percent } \\
\text { contemporary } \dagger\end{array}$ & Model** \\
\hline 1 & Oct-18-77 & 3 & Slash & 150 & Total & $47 \pm 12 \#$ & 96 \\
\hline 2 & Oct-18-77 & 1 & Slash & 26 & Fine & $107 \pm 18$ & 96 \\
\hline 3 & Oct-18-77 & 3 & Slash & 49 & Fine & $80 \pm 15$ & 96 \\
\hline 4 & Jan-23-78 & 5 & RWC & 68 & Fine & $62 \pm 13 \#$ & 109 \\
\hline 5 & Jan-23-78 & 3 & RWC & 200 & Total & $45 \pm 12 \#$ & 109 \\
\hline 6 & Aug-17-77 & 3 & $\begin{array}{l}\text { Violation } \\
\text { (no burning) }\end{array}$ & 140 & Total & $77 \pm 15 \#$ & 0 \\
\hline 7 & Aug-11-78 & $\mathbf{L}$ & Field & 74 & Fine & $107 \pm 15$ & 100 \\
\hline 8 & Aug- $3-78$ & C & Slash & 42 & Fine & $76 \pm 12$ & 96 \\
\hline 9 & Aug- 3-78 & $\mathbf{E}$ & Slash & 150 & Total & $104 \pm 16$ & 96 \\
\hline
\end{tabular}

* Contemporary carbon was determined by counting ${ }^{14} \mathrm{C}$ for $14-62$ hours in $5 \mathrm{~mL}$ and $15 \mathrm{~mL}$ counters (4 and 1 atmospheres $\mathrm{CO}_{2}$, respectively). Measured samples consisted of 5.1-10.7mg-C; total available carbon ranged from $11-72 \mathrm{mg}$. Data from Cooper, Currie, and Klouda (in press). ** The four impact categories are used to derive the model contemporary carbon percentages; $\mathrm{RWC}=$ Residential wood combustion.

$\dagger$ Uncertainties represent Poisson standard deviations; \# indicates statistically significant deviation from the (single-source) model.

I Site 1 was the north upwind background site, site 3 was the downtown Portland site, site 5 was located in a southeast Portland residential area, and $\mathrm{L}=$ Lebanon, $\mathrm{C}=\mathrm{Coburn}$, and $\mathbf{E}=$ Eugene, Oregon.

I Carbon ranged from 14 to 49 percent of the total particle mass. 
inventory to produce significant urban burdens of respirable particles. The fact that the typical combustion process is incomplete exacerbates the health hazard, because the resultant soot particles contain dangerous amounts of carcinogenic and mutagenic hydrocarbons.

\section{CONCLUSION}

Both predictive (inventories, modeling) and circumstantial (isotopic, chemical composition) evidence demonstrate that man's activities are beginning to significantly perturb the natural environment. Chemical alteration of the atmosphere is one of the most serious perturbations because of the direct health effects and disturbances of the earth's radiation balance, but changes in visibility and hydroxyl radical concentrations (therefore tropospheric lifetimes) must not be ignored. Because of the very important role of carbonaceous gases and particles in these changes, radiocarbon will become increasingly valuable as a monitor for biogenic and fossil emissions. Meriting particular attention in this regard is "soot," the fine particle fraction consisting largely of elemental carbon and high molecular weight hydrocarbons, which will appear in increasing abundance as energy economics forces a transition to wood, coal, and diesel fuel (Carter, 1979; Pierson, 1979).

Improvements in our ability to use radiocarbon as a diagnostic tool are due primarily to: 1) important advances in radiocarbon measurement techniques that permit reliable assay of as little as $5 \mathrm{mg}$ of environmental carbon, and 2) major increases in the information content of the isotopic measurments through the pre-selection of specific physical or chemical fractions or through parallel chemical data related to inorganic and/or organic composition. One of the most important steps that we shall take in the near future is to incorporate the physical, chemical, and isotopic measurements more formally into a comprehensive CMB and sampling design in order to optimize both pollutant source resolving power and error (assumption, measurement) detection.

TABLE 3

Comparison of indicators for field, slash, and residential wood combustion particles*

\begin{tabular}{|c|c|c|c|c|c|c|}
\hline \multicolumn{7}{|c|}{ (fine particles) } \\
\hline \multirow[b]{2}{*}{$\begin{array}{l}\text { Vegetative } \\
\text { impact }\end{array}$} & \multirow[b]{2}{*}{$\begin{array}{l}\text { Filter } \\
\text { no. }\end{array}$} & \multicolumn{2}{|c|}{ Vegetative carbon $(\%)$} & \multirow[b]{2}{*}{$\mathrm{K} / \mathrm{Fe}$} & \multirow[b]{2}{*}{ Fine/Total } & \multirow[b]{2}{*}{$\begin{array}{c}\text { Concentration } \\
\left(\mu \mathrm{g} / \mathrm{m}^{2}\right)\end{array}$} \\
\hline & & $\begin{array}{l}\text { Radiocarbon } \\
\text { measurement }\end{array}$ & $\begin{array}{l}\text { Budget } \\
\text { estimate }\end{array}$ & & & \\
\hline Field & 7 & $107 . \pm 15$ & 99 & 57 & 0.71 & 36. \\
\hline \multirow[t]{3}{*}{ Slash } & 2 & $111 \pm 19$ & 85 & 7.4 & 0.28 & 7.0 \\
\hline & 3 & $83 . \pm 16$ & 78 & 1.49 & 0.33 & 17. \\
\hline & 8 & $79 . \pm 12$ & 97 & 2.4 & 0.32 & 21. \\
\hline $\begin{array}{l}\text { Residential } \\
\text { wood }\end{array}$ & 4 & $57 . \pm 12$ & 79 & 2.6 & - & 24. \\
\hline
\end{tabular}

* Radiocarbon errors represent one (Poisson) standard deviation; other indicators, which are subject to significant assumption-related uncertainties, are given for qualitative comparison (Cooper, Currie, and Klouda, in press). 


\author{
WOOD BURNING \\ Utilization \\ - Scandinavia: Finland projects $30 \%$ (by end of \\ 1980's); Sweden, $58 \%$ (by 2015) \\ - U.S.: $\quad$ A major fuel, ranks with hydroelec- \\ tric and nuclear (wood stove sales: \\ $10^{6} / y r$.) \\ Environmental Significance \\ - Particle emissions: 20-50 times oil, gas/Btu, pri- \\ marily fines (respirable) \\ - Incomplete combustion $\rightarrow$ soot, PAH, HCHO, \\ phenols, ... \\ Observed Impacts \\ - Bangor, ME: $8 \mu \mathrm{g} / \mathrm{m}^{3}$ (inventory) \\ - Portland, OR: $24 \mu \mathrm{g} / \mathrm{m}^{3}$ (radiocarbon)
}

Fig 4. Wood as a fuel: utilization and particulate pollution. Information on wood utilization may be found in Brooke (1979) and Trefil (1978), on environmental significance and impacts, in Cooper, Currie, and Klouda (in press) and Butcher (1978).

Of critical importance to our program to resolve individual sources of carbonaceous species, and to increase our knowledge of spatial and temporal variations, is the ability to determine radiocarbon in extremely small samples. While small proportional counters will continue to provide much of the information we need, reliably and inexpensively, a major promise for the future is direct ${ }^{14} \mathrm{C}$ atom counting by means of Accelerator Mass Spectrometry (AMS) (Gove, 1978; Muller, 1977). The ability to determine natural radiocarbon in microgram samples will permit us to assay gaseous halocarbons, aromatic hydrocarbons, and trapped or adsorbed polycyclic and oxygenated organic compounds that have allegedly arisen from anthropogenic or natural sources.

Our first experiment to evaluate AMS for the reliable determination of natural radiocarbon in $\mu \mathrm{g}$ samples was made in July 1979, which will be fully reported elsewhere (Currie and others, ms in preparation). Among the conclusions of this exploratory study, however, were the facts that it appears possible 1 ) to apply the technique directly to atmospheric particles, 2) to enrich the sample and overcome most of the machine background by means of an initial, isotope separator implantation step, and 3) to reliably assay less than $40 \mu \mathrm{g}$ of contemporary carbon. The last result, which was obtained using the new international radiocarbon dating standard, represents an experimental upper limit because a significant fraction of the initial carbon remained in the ion source sample cup when the accelerator experiment was terminated.

\title{
ACKNOWLEDGMENTS
}

Partial support by the Oregon Department of Environmental Quality, the Office of Environmental Measurements (NBS), and the EPA Energy-Environment Program (EPA-IAG-DG-E684) is gratefully acknowl- 
edged. Mention of commercial products in the text does not imply endorsement by NBS.

\section{REFERENCES}

Altshuler, A P, 1978, Methylchloroform in the stratosphere: Science, v 200, p 718-722.

Blumer, M and Youngblood, W W, 1975, Polycyclic aromatic hydrocarbons in soils and recent sediments: Science, v 188, p 53-55.

Bolin, B, 1977, The impact of production and use of energy on the global climate: Ann Rev Energy, v 2, p 197-226.

Brooke, J B, 1979, Chips are down in industry's gamble on wood power: New York Times, 21 October.

Butcher, S S, 1978, Final report to the Bureau of Air Quality Control, Maine Dept Environmental Protection: sec III, Preliminary analysis of particulate matter from small wood stoves, December.

Calder, J A and Parker, P L, 1968, Stable isotope ratios as indices of petrochemical pollution of aquatic systems: Environmental Sci Technol, v 7, p 535-539.

Carter, L J, 1979, Decisions near on diesels: Science, v 206, p 1381.

Clayton, G D, Arnold, J R, and Patty, F A, 1955, Determination of sources of particulate atmospheric carbon: Science, v 122, p 751-753.

Coffey, P E and Stasink, W M, Jr, 1975, Evidence of atmospheric transport of ozone into urban areas: Environmental Sci Technol, v 9, p 59-66.

Cooper, J A, Currie, L A, and Klouda, G A, 1979, Evaluation of carbon-14 as a unique tracer to determine the maximum impact of contemporary carbon sources of atmospheric particulates in the Portland and Eugene airsheds: Final rept, Oregon Dept Environmental Quality, May.

in press, Application of carbon-14 measurements to impact assessment of contemporary carbon source on urban air quality: Environmental Sci Technol, in press.

Cooper, J A, Watson, J G, and Huntzicker, J J, 1979, Summary of the Portland aerosol characterization study: Air Pollution Control Assoc Mtg, 72nd, Paper 79-29.4.

Core, J E, and Terraglio, F P, 1978, Field and slash burning particulate characterization: The search for unique natural tracers: Air Pollution Control Assoc rept.

Currie, L A, Kunen, S M, Voorhees, K J, Murphy, R B, and Koch, W F, 1978, Analysis of carbonaceous particulates and characterization of their sources by low-level radiocarbon counting and pyrolysis/gas chromatography/mass spectrometry: Carbonaceous particles in the atmosphere, Conf, Proc, Univ California, Berkeley, p 36-48.

Currie, L A, Noakes, J, and Breiter, D, 1979, Measurement of small radiocarbon samples: Power of alternative methods for tracing atmospheric hydrocarbons, in Berger, Rainer and Suess, H E, eds, Radiocarbon dating, Internatl radiocarbon Conf, 9th, Proc: Berkeley/Los Angeles, Univ California Press, p 158-175.

Friedlander, S K, 1973, Chemical element balances and identification of air pollution sources: Environmental Sci Technol, v 7, p 235-240.

Geophysics Study Committee, 1977, Energy and climate: NRC Geophysics Research Board, Natl Acad Sci, Washington, DC.

Gove, H E, ed, 1978, Conference on radiocarbon dating with accelerators, 1st, Proc: Univ Rochester. (See also Currie, L A, Environmental radiocarbon measurements, p 372-390.)

Hall, C A S, Howarth, R, Moore, B, and Vörösmarty, C J, 1978, Environmental impacts of industrial energy systems in the coastal zone: Ann Rev Energy, v 3, p 395-475.

Hites, R A, Laflamme, R E, and Farrington, J W, 1977, Sedimentary polycyclic aromatic hydrocarbons: The historical record: Science, v 198, p 829-831.

Lodge, J P, Jr, Bien, G S, and Suess, H E, 1960, The carbon-14 contents of urban airborne particulate matter: Internatl Jour Air Pollution, v 2, p 309-312.

Logan, J A, Prather, M J, Wofsy, S C, and McElroy, M B, 1978, Atmospheric chemistry: Response to human influence: Royal Soc [London] Philos Trans, v B290, p 187-234.

Lopes, J S, Pinto, R E, Almendra, M E, and Machado, J A, 1975, Variation of ${ }^{14} \mathrm{C}$ activity in Portuguese wines from 1940 to 1974, in Internatl conf on low-radioactivity measurements and applications, Proc: The High Tatras, Czechoslovakia, p 265-268.

Muller, R A, 1977, Radioisotope dating with a cyclotron: Science, v 196, p 489-494.

Novakov, T, ed, 1978, Conference on carbonaceous particles in the atmosphere, Proc: LBL-9037 (Lawrence Berkeley Lab). 
Pierson, W R, 1979, Particulate organic matter and total carbon from vehicles on the road, in Novakov, $\mathrm{T}$, ed, Conf on carbonaceous particles in the atmosphere, Proc: LBL-9037 (Lawrence Berkeley Lab) p 221-228.

Rasmussen, R A, 1972, What do the hydrocarbons from trees contribute to air pollution?: Air Pollution Control Assoc Jour, v 22, p 537-543.

Rowland, F S and Molina, M J, 1975, Cholofluoromethanes in the environment: Rev Geophysics Space Physics, v 13, p 1-35.

Schutz, D F and Renwick, A, 1977, Measurement of carbon isotope ratios in volatile hydrocarbons derived from plants: Final rept, Coordinating Research CouncilAPRAC Proj No. CAPA-11-71. Trefil, J S, 1978, Wood stoves glow warmly again in millions of homes: Smithsonian,
v 9, p 55-62.

Troughton, J H, 1972, Carbon isotope fractionation by plants, in Rafter, T A and Grant-Taylor, $T$, eds, Internatl radiocarbon dating conf, 8th, Proc: Wellington, Royal Soc New Zealand, v 2, p 420-438.

Watson, J G, 1979, Chemical element balance receptor model methodology for assessing the sources of fine and total suspended particulate matter in Portland, Oregon: PhD thesis, Oregon Graduate Center, Beaverton, Oregon. 